\title{
PODŻEGANIE I POMOCNICTWO JAKO TYPY ZJAWISKOWE PRZESTĘPSTWA
}

\section{WPROWADZENIE}

Artykuł stanowi próbę nowego otwarcia dyskusji na tematy teoretycznych podstaw odpowiedzialności karnej za przestępne współdziałanie w polskim prawie karnym. Analizując modyfikacje modeli tej odpowiedzialności (teorie: udziału w cudzym przestępstwie, jednolitego sprawstwa i postaci zjawiskowych), autor stara się zaprezentować aktualne poglądy na temat różnic między alternatywnymi ujęciami. Opracowanie stanowi także propozycję zmian legislacyjnych w obrębie rozdziału II Kodeksu karnego z 1997 r.

Regulacja zasad odpowiedzialności karnej za formy przestępnego współdziałania należy do najciekawszych i najdonioślejszych zagadnień nauki o przestępstwie. Podstawą wszelkich rozważań na temat postaci popełnienia czynu zabronionego jest wyjaśnienie funkcji opisu typu przestępstwa, zawartego w części szczególnej ustawy karnej. W zależności od przyjmowanych założeń teoretycznych i aksjologicznych należy odpowiedzieć na pytanie, czy wynikający z tego opisu zespół ustawowych znamion przestępstwa pozwala na pociagnięcie do odpowiedzialności karnej jedynie osobę, która bezpośrednio sprowadza ujemnie oceniany stan rzeczy, czy też pozwala na objęcie odpowiedzialnościa także innych osób, które do realizacji przestępstwa jedynie się przyczyniaja. Teoretyczne podstawy odpowiedzialności karnej za przestępne współdziałanie wymagają zatem wyważenia gwarancyjnej i ochronnej funkcji prawa karnego.

Jednocześnie stan polskiej nauki prawa karnego wymaga pogłębionej refleksji na temat zasad odpowiedzialności karnej za sprawstwo, podżeganie i pomocnictwo. Jak słusznie zauważają Michał Królikowski i Robert Zawłocki, formy współdziałania przestępnego przyjęło się nazywać formami zjawiskowymi popełnienia przestępstwa, co czyni się także współcześnie, choć pojęcie to oderwało się od jego modelowego ujęcia i znaczenia ${ }^{1}$. Przedstawiciele nauki prawa karnego i judykatura zakwestionowali szereg założeń składających się na teorię postaci zjawiskowych (opracowana przez Juliusza Makarewicza), co powoduje liczne problemy natury teoretycznej i praktycznej. Mimo odrzucenia tych założeń przepisy Kodeksu karnego z 1997 r., przynajmniej formalnie,

${ }^{1}$ M. Królikowski, R. Zawłocki, Prawo karne, Warszawa 2015, s. 224-225. 
nadal opierają się na ujęciu podżegania i pomocnictwa jako odmiennych niż sprawstwo form popełnienia przestępstwa opisanego w przepisie typizujacym części szczególnej². Trzeba mieć także na uwadze, że opracowane w nauce prawa karnego teorie współdziałania przestępnego zostały istotnie zmodyfikowane, zgodnie z założeniami współczesnego prawa karnego, i nie występuja obecnie w ujęciach modelowych. Powoduje to, że pewne argumenty przemawiające przeciwko założeniom teorii udziału w cudzym przestępstwie, które były podstawą opracowanej przez J. Makarewicza koncepcji postaci zjawiskowych przestępstwa, uległy dezaktualizacji. Wydaje się, że wszystkie te okoliczności wskazują na to, że zachodzi potrzeba rozważenia rewizji podstaw teoretycznych odpowiedzialności karnej za przestępne współdziałanie w polskim prawie karnym. Próbę taka podjęła w 2013 r. Komisja Kodyfikacyjna Prawa Karnego przy Ministrze Sprawiedliwości ${ }^{3}$.

\section{MODELE ODPOWIEDZIALNOŚCI KARNEJ ZA PRZESTEZPNE WSPÓŁDZIAŁANIE I JEJ WSPÓŁCZESNE MODYFIKACJE}

W nauce prawa karnego wykształcono trzy modele odpowiedzialności karnej za przestępne współdziałanie. Według teorii udziału w cudzym przestępstwie (Teilnahmesystem) przestępstwem jest jedynie czyn opisany w części szczególnej ustawy, opisujący zabronione zachowanie. Sprawca przestępstwa jest tylko osoba, która wykonuje czyn zabroniony, sprowadzając swoim własnym czynem ujemnie oceniany stan rzeczy ${ }^{4}$. Osoby, które przyczyniają się do tego, że sprawca popełnia przestępstwo, mogą odpowiadać tylko za udział w tym przestępstwie. Ponieważ nie wykonują oni znamion typu opisanego w części szczególnej, pociagnięcie ich do odpowiedzialności jest możliwe tylko o tyle, o ile ich zachowanie zostanie opisane w ustawie, rozszerzajac tym samym zakres odpowiedzialności karnej. Konsekwencją założenia, że współdziałający (uczestnik) odpowiada za udział w cudzym przestępstwie, jest akcesoryjność odpowiedzialności ${ }^{5}$. Przez akcesoryjność należy rozumieć uzależnienie odpowiedzialności współdziałającego od popełnienia przestępstwa przez sprawcę ${ }^{6}$.

2 A. Zoll, głos w dyskusji, w: J. Majewski (red.), Formy stadialne i postacie zjawiskowe popetnienia przestepstwa. Materiaty III Bielańskiego Kolokwium Karnistycznego, Toruń 2007, s. $164-165$.

${ }^{3}$ A. Zoll, Prace nad nowelizacja przepisów części ogólnej kodeksu karnego, „Państwo i Prawo” 67, 2012, z. 11, s. 7-8.

${ }^{4}$ R. Herzberg, Sprawstwo i udziat w przestepstwie, „Studia Prawnicze” 1988, z. 1-2, s. 146.

${ }^{5}$ H. Jescheck, T. Weigend, Lehrbuch des Strafrecht. Allgemeiner Teil, Berlin-New York 1996, s. 646; R. Herzberg, op. cit., s. 156.

${ }^{6}$ L. Tyszkiewicz, Współdziałanie przestępne i główne pojęcia z nim zwiazane w polskim prawie karnym, Poznań 1964, s. 65-66. Uzależnienie odpowiedzialności współdziałających od popełnienia przestępstwa przez sprawcę jest nazywane akcesoryjnością kwalifikatywną (jakościowa). Innym obrazem akcesoryjności jest jej ujęcie kwantytatywne (ilościowe), polegające na tym, że zakres represji karnej grożącej współdziałającym jest uzależniony od tego, czy sprawca dokona czynu, usiłuje go dokonać, czy nawet nie usiłuje dokonać. 
Zgodnie z założeniami teorii jednolitego sprawstwa (Einheitstätersystem) za sprawcę czynu opisanego w części szczególnej należy uważać nie tylko tego, kto bezpośrednio realizuje znamię czasownikowe, lecz każdego, czyje zachowanie było koniecznym warunkiem popełnienia przestępstwa. Współdziałanie przestępne stanowi więc zbieg przestępstw, gdyż każda osoba wykonująca czyn przyczyniający się do zrealizowania znamion typu popełnia własne przestępstwo (quot delinquentes, tot delicta). Odpowiedzialność każdego sprawcy jest niezależna od odpowiedzialności pozostałych ${ }^{7}$.

Opracowana przez J. Makarewicza teoria postaci zjawiskowych przestępstwa czerpie z obu wskazanych wyżej modeli ${ }^{8}$. Zgodnie z jej założeniami każda osoba, która przyczynia się do popełnienia przez sprawcę przestępstwa, powinna odpowiadać za własne przestępstwo. Ustawa karna, zgodnie z zasada nullum crimen sine lege, powinna opisać karalne formy współdziałania przestępnego. Formy te stanowią odmienny sposób zaatakowania dobra prawnego i postacie zjawiskowe przestępstwa opisanego w części szczególnej ${ }^{9}$. Każde przestępstwo rodzajowe może być popełnione w formie sprawstwa, podżegania albo pomocnictwa. Podżegacz i pomocnik nie sa jedynie uczestnikami przestępstwa popełnionego przez sprawcę, ale nie są téz jego sprawcami. „Sprawstwo" podżegania i pomocnictwa jest sprawstwem odmiennego rodzaju niż sprawstwo przestępstwa rodzajowego. Odpowiedzialność podżegacza i pomocnika nie jest akcesoryjna względem odpowiedzialności sprawcy, ale związek pomiędzy czynami poszczególnych współdziałających uzasadnia uzależnienie represji karnej grożącej współdziałajaccym od tego, czy sprawca dokona przestępstwa.

Opisane wyżej modelowe ujęcia zasad odpowiedzialności karnej za przestępne współdziałanie zostały istotnie zmodyfikowane. W niemieckim prawie karnym, przyjmującym założenia teorii udziału, zakres akcesoryjności był $\mathrm{w}$ ramach kolejnych reform ograniczany ${ }^{10}$. W ujęciu modelowym akcesoryjność oznacza, że odpowiedzialność współdziałającego jest uzależniona od popełnienia przez sprawcę czynu bezprawnego, realizującego znamiona przestępstwa i zawinionego ${ }^{11}$. Konsekwencje praktyczne tego założenia okazały się jednak niemożliwe do pogodzenia z celami polityki karnej. Prowadziło to wszakże do bezkarności podżegacza czy pomocnika także wówczas, gdy wykorzystując osobę nieponoszącą winy (np. nieletniego lub niepoczytalnego), realizowali własny zamiar przestępny ${ }^{12}$. Z tych względów na mocy reformy prawa karnego z 1943 r. uniezależniono odpowiedzialność uczestników od zawinienia

7 D. Kienapfel, Die Einheitstäterregelung der $\$ \S 12$ und 32 StGB Fortsetzung und Schluss, „Juristische Blätter” 1974, z. 7-8, s. 120.

8 P. Kardas, Teoretyczne podstawy odpowiedzialności karnej za przestepne współdziałanie, Kraków 2001, s. 410-417.

9 J. Makarewicz, Kodeks karny z komentarzem, Lwów 1938 (reprint Lublin 2012), s. 128.

10 P. Kardas, op. cit., s. 215.

11 H. Jescheck, T. Weigend, op. cit., s. 655.

12 Negatywne konsekwencje winy akcesoryjnej doprowadziły do tego, że w niemieckiej nauce prawa karnego wypracowano konstrukcję sprawstwa pośredniego, zaakceptowaną przez judykaturę. Zob. H. Welzel, Das deutsche Strafrecht, Berlin 1989, s. 101-102. 
sprawcy, statuując tzw. ograniczoną akcesoryjnośćc ${ }^{13}$. Reformę doprowadzono do końca ustawą z 4 lipca 1960 r., na mocy której uzależniono odpowiedzialność podżegacza i pomocnika od popełnienia przez sprawcę umyślnie czynu bezprawnego (akcesoryjność minimalna).

Podstawa reformy niemieckiego prawa karnego nie sprowadzała się jedynie do dostrzeżenia konsekwencji maksymalnej akcesoryjności odpowiedzialności uczestników. Poszukując podstaw odpowiedzialności karnej za przestępne współdziałanie, dostrzeżono, że jest ona uzasadniona nie tylko dlatego, że współdziałający uczestniczą w przestępstwie popełnianym przez sprawcę, lecz także z uwagi na charakteryzujący ich zachowanie zły zamiar, ukierunkowany na spowodowanie popełnienia przestęstwa ${ }^{14}$. Pomimo bliskiego związu form współdziałania przestępnego ze sprawstwem, tych pierwszych nie można całkowicie pozbawić samodzielnego charakteru, tym bardziej jeśli przyjaćc, że ustawodawca powinien zakazywać pod groźbą kary jedynie zachowań społecznie niebezpiecznych (nullum crimen sine periculo sociali).

Co więcej, nie do pogodzenia z konstytucyjna zasadą nullum crimen sine lege byłoby przyjęcie, że podżeganie i pomocnictwo, skoro są typowymi zachowaniami, z którymi wiązać się może odpowiedzialność karna, nie są czynami zabronionymi, a jedynie udziałem w cudzym przestępstwie ${ }^{15}$. Wszystko to doprowadziło do zasadniczego zmodyfikowania założeń Teilnahmesystem. Współcześnie należałoby więc powiedzieć, że cechą charakterystyczną tego modelu jest uznanie, że formy współdziałania przestępnego stanowią powiązane ze sprawstwem przestępstwa. Uzasadnieniem ich karalności jest przede wszystkim przyczynienie się do popełnienia czynu bezprawnego przez inną osobę, ale także zamiar spowodowania przestępstwa ${ }^{16}$. Zminimalizowana akcesoryjność odpowiedzialności uczestników wynika z decyzji ustawodawcy opartej na założeniu, że głównym powodem karalności podżegania i pomocnictwa jest przyczynienie się do popełnienia przestępstwa przez inną osobę. Nie wynika ona $\mathrm{z}$ samej istoty podżegania i pomocnictwa, ale jest rezultatem autonomicznej decyzji ustawodawcy ${ }^{17}$. Konkluzywnie można powiedzieć, że niemieckie prawo

${ }^{13}$ H. Welzel, Abhandlungen zum Strafrecht und zur Rechtsphilosophie, Berlin 1973, s. 165-166.

${ }^{14}$ H. Jescheck, T. Weigend, op. cit., s. 685; G. Jakobs, Strafrecht. Allgemeiner Teil. Die Grundlagenund die Zurechnuglslehre, Berlin 1991, s. 657-658; E. Schmidhäuser, Strafrecht. Allgemeiner Teil 2, Opladen 1984, s. 268-271. Pogląd upatrujący znacznego usamodzielnienia podżegania i pomocnictwa od sprawstwa, dostrzegający samodzielną ujemność form współdziałania przestępnego, jest znany jako die reine Verursachungstheori (,teoria spowodowania”). Zob. J. Renzikowski, Restriktiver Täterbegriff und fahrlässige Beteiligung, Tübingen 1996, s. 45-46; C. Roxin, Zum Strafgrund der Teilnahme, w: W. Kuper, J. Welp (Hrsg.), Beitrage zur Rechtswissenschaft. Festschrift für Walter Stree und Johannes Wessels zum 70. Geburtstag, Heidelberg 1993, s. 365-380.

${ }^{15}$ C. Roxin, op. cit., s. 375-380.

${ }^{16}$ Koncepcja ta nazywana jest Akzessorietätsorientierte Verursachungstheorie, czyli „teoria spowodowania zorientowaną na akcesoryjność”. Wyjaśnia ona samodzielność bezprawia form uczestnictwa z jednej, a ich akcesoryjność względem sprawstwa głównego w płaszczyźnie karalności z drugiej strony. Zob. J. Renzikowski, op. cit., s. 44-46; V. Damnjanović, Die Beteiligungsformen im deutschen und serbischen Strafrecht sowie in der ICTY-Rechtsprechung, Berlin 2013, s. 50-51; R. Herzberg, op. cit., s. 158-159; P. Hünerfeld, Sprawstwo pośrednie i podżeganie w prawie karnym RFN, „Studia Prawnicze” 1988, z. 1-2, s. 217-218.

17 J. Makarewicz, Przestęptwo indywidualne a orzecznictwo Sadu Najwyższego, „Gazeta Sądowa Warszawska” 1934, z. 39, s. 518-519. W tym też rozumieniu ma rację R. Herzberg, op. cit., 
karne nie przyjmuje modelu udziału w cudzym przestępstwie, ale jego modyfikację, którą można by uznać za teorię udziału w cudzym czynie ${ }^{18}$.

Również modelowe założenia teorii jednolitego sprawstwa nie mogły zostać wprowadzone do ustawy karnej bez narażenia na zarzut naruszenia zasady nullum crimen sine lege. W ujęciu modelowym Einheitstätersystem nie ma w ogóle potrzeby ustawowego określenia sprawstwa (formale Einheitstätersystem) ${ }^{19}$. Oznacza to jednak niezwykle szeroki zakres odpowiedzialności wynikający z ekstensywnie ujmowanego sprawstwa przestępstwa. Zakres ten należy ograniczyć przez odpowiednią regulację zawartą w części ogólnej lub szczególnej, polegajaccą na ustawowym określeniu karalnych form przyczynienia się do realizacji przestępstwa (funktionale Einheitstätersystem) ${ }^{20}$. Taką regulację przyjmuje się w austriackim prawie karnym, rozróżniającym sprawstwo pojedyncze, podżegające i przyczyniające. Rozróżnienie form sprawstwa powoduje jednak, że ustawa rozróżnia typ zachowania polegający na wykonaniu przestępstwa i na przyczynieniu się do jego wykonania, co niejako automatycznie wprowadza dyferencjację odpowiedzialności poszczególnych sprawców. Każdy ze sprawców przyczynia się do popełnienia przestępstwa, zachowując się w określony w ustawie sposób, co prowadzi do wniosku, że każdy z nich odpowiada za odmiennie opisane przestępstwo, będące jednak sprawstwem tego samego typu przestępstwa ${ }^{21}$.

Jak wskazano już na początku, istotną ewolucję przeszły także poglądy przedstawicieli polskiej nauki prawa karnego i orzecznictwo sądowe. Jedna z podstaw teorii postaci zjawiskowych było waskie rozumienie sprawstwa, ujętego jako samodzielne wykonanie przestępstwa. Wydaje się, że rozszerzenie pojęcia sprawstwa na jego postacie niewykonawcze w kodeksach z 1969 i 1997 r. (sprawstwo kierownicze i polecajace) stanowiło zaprzeczenie tego założenia. Uznanie za sprawcę także osób, które nie wykonują czynu zabronionego, ale sprawują władztwo nad osobą wykonawcy, przeczy założeniu o równorzędności form technicznych popełnienia przestępstwa. Co więcej, ograniczenie odpowiedzialności karnej do popełnienia czynu zabronionego, a więc zachowania o znamionach określonych w ustawie karnej, prowadzi do wniosku, że także

s. 156, który twierdził, że: „[...] uczestnictwo w przestępstwie - bez zmiany swojej istoty - nie może być ustawowo inaczej ukształtowane, jak tylko w postaci akcesoryjnej”. Jest to prawda pod warunkiem, że ustawodawca podejmie decyzję o tym, by ukształtować podżeganie i pomocnictwo jako formy uczestnictwa, a nie niezależne przestępstwa, których karalność opiera się w pierwszej kolejności na ich zamiarze spowodowania przestępstwa.

${ }_{18}$ Por. L. Tyszkiewicz, op. cit., s. 68-70.

${ }^{19}$ D. Kienapfel, Grundriss des österreichischen Strafrecht. Allgemeiner Teil, Wien 1998, s. 192. Warto zwrócić uwagę, że podobne stanowisko przyjął J. Makarewicz, Kodeks karny z komentarzem, Lwów 1932, s. 86.

${ }^{20}$ D. Kienapfel, Die Einheitstäterregelung..., s. 120. Regulacja zawarta w części ogólnej polega na podaniu ogólnego ujęcia sprawstwa, które będzie się odnosić do wszystkich typów przestępstw opisanych w części szczególnej. Odmienna technika legislacyjna polega na uzupełnieniu znamion tych typów w części szczególnej, przez dodanie znamion wskazujących na karygodne formy przyczynienia się. Zob. P. Kardas, op. cit., s. 36-37; L. Tyszkiewicz, op. cit., s. 35.

${ }^{21}$ D. Kienapfel, Grundriss..., s. 192-194; K. Schmoller, Grundstriktionem der Beteiligung mehrere an einer Straftat - die objektive Zurechnung fremden Verhaltens, „Österreichische Juristen Zeitung" 1983, z. 13, s. 347. 
podżeganie i pomocnictwo, jako zachowania karalne na gruncie ustawy karnej, sa czynami zabronionymi. Opis zachowania podżegacza i pomocnika wskazuje nadto, że swoim postępowaniem wyczerpują oni odmienny niż sprawca zespół ustawowych znamion, są więc sprawcami innego typu czynu zabronionego. Sprawstwo podżegania i pomocnictwa odnosi się więc do innego typu czynu niż sprawstwo osoby wykonującej znamiona przestępstwa określone w części szczególnej, nie są więc postaciami zjawiskowymi przestępstwa ${ }^{22}$.

\section{KONSEKWENCJE MODYFIKACJI TEORII POSTACI ZJAWISKOWYCH POPEŁNIENIA PRZESTĘPSTWA}

Zmiana sposobu myślenia o normatywnej konstrukcji podżegania i pomocnictwa oraz rozszerzenie pojęcia sprawstwa nakazują rozważyć, czy polskie prawo karne pozostaje wierne założeniom J. Makarewicza i jego teorii postaci zjawiskowych. W nauce prawa karnego zakwestionowano taka podstawę teoretyczną regulacji odpowiedzialności karnej za przestępne współdziałanie ${ }^{23}$. Jednocześnie mając na uwadze istotne modyfikacje, jakich doświadczyły teoria udziału w cudzym przestępstwie i teoria jednolitego sprawstwa, należy się zastanowić, czy polska nauka prawa karnego nie obrała jednego ze wskazanych w tych koncepcjach kierunku.

W poglądach przedstawicieli polskiej nauki prawa karnego zawsze podkreślano, że odpowiedzialność podżegacza i pomocnika jest oparta na negatywnej ocenie ich własnego zachowania. Karalność form współdziałania przestępnego nie jest jedynie pochodna zachowania sprawcy ${ }^{24}$. Podżegacz jest wszak-

${ }_{22}$ A. Zoll, Czy podżeganie i pomocnictwo sq postaciami zjawiskowymi przestępstwa?, w: J. Giezek (red.), Przestepstwo - kara - polityka kryminalna. Problemy tworzenia i funkcjonowania prawa. Księga jubileuszowa $z$ okazji 70 rocznicy urodzin Profesora Tomasza Kaczmarka, Kraków 2006.

${ }^{23}$ M. Bielski, Sprawstwo zleceniodawcze w projekcie nowelizacji kodeksu karnego, „Prokuratura i Prawo" 2006, z. 10, s. 47; L. Gardocki, Prawo karne, Warszawa 2008, s. 99; R. Dębski, O teoretycznych podstawach regulacji wspótdziałania przestępnego w kodeksie karnym z $1997 \mathrm{r}$., „Studia Prawno-Ekonomiczne” 1998, z. 58, s. 124; J. Giezek, w: idem, N. Kłączyńska, G. Łabuda, Kodeks karny. Część ogólna. Komentarz, Warszawa 2012, s. 172; T. Kaczmarek, rec.: Piotr Kardas, Teoretyczne podstawy odpowiedzialności karnej za przestepne wspótdziatanie, „Prokuratura i Prawo” 2002, z. 5, s. 101; P. Kardas, op. cit., s. 560-561; A. Liszewska, Wspótdziałanie przestepne w polskim prawie karnym. Analiza dogmatyczna, Łódź 2004, s. 106-110; A. Marek, Kodeks karny. Komentarz, Warszawa 2010, s. 73; Ł. Pohl, Prawo karne. Wykład części ogólnej, Warszawa 2013, s. 161; A. Spotowski, Funkcja niebezpieczeństwa w prawie karnym, Warszawa 1990, s. 183; W. Wróbel, A. Zoll, Polskie prawo karne. Część ogólna, Kraków 2010, s. 266; A. Zoll, Sprawstwo bez wykonania czynu zabronionego, „Ruch Prawniczy, Ekonomiczny i Socjologiczny” 71, 2009, z. 2, s. $177-178$.

${ }^{24}$ L. Tyszkiewicz, op. cit., s. 140-143; W. Bugajski, Zamiar $i$ wina w podżeganiu i pomocnictwie, „Nowe Prawo” 1964, z. 11, s. 1062; Z. Papierkowski, Postacie zjawiskowe przestepstwa (art. 28-38), „Państwo i Prawo” 18, 1963, z. 4, s. 679; J. Giezek, op. cit., s. 162; J. Makarewicz, Kodeks karny..., s. 130; K. Buchała, w: idem et al., Komentarz do kodeksu karnego. Część ogólna, Warszawa 1994, s. 136; S. Śliwiński, O niektórych zagadnieniach ogólnych przyszłego kodeksu karnego PRL, „Nowe Prawo” 1955, z. 1, s. 32-33; A. Spotowski, op. cit., s. 185-186; P. Kardas, 
że „osoba, od której pierwsza przyczyna i pobudka do występku pochodzi” ${ }^{25}$, „duchowym twórcą" przestępstwa ${ }^{26}$, jego „moralnym autorem”"27, „sprężyną"28 lub „sprawcą intelektualnym” ${ }^{29}$. Nie można więc powiedzieć, aby poglądy na podstawę karalności podżegania i pomocnictwa stanowiły prosta recepcję na grunt polskiego prawa karnego założeń teorii udziału w cudzym czynie.

Polski ustawodawca nie uznaje jednak podżegania i pomocnictwa za postacie sprawstwa przestępstwa rodzajowego, określonego w części szczególnej. Nie przyjmuje więc założeń teorii jednolitego sprawstwa ani w jego ujęciu modelowym (formalnym), ani funkcjonalnym. Również rozszerzone formy sprawstwa, a więc sprawstwo kierownicze i polecające zdaje się, że nie nawiązują do koncepcji sprawstwa ekstensywnego. Podstawą tego ostatniego nie jest rozszerzenie sprawstwa poza przypadki własnoręcznego wykonania przestępstwa, ale uznanie, że sprawstwo przestępstwa rodzajowego jest jedyną formą odpowiedzialności karnej. Tymczasem polskie prawo karne zna nie tylko postacie sprawstwa, ale także swoiste sprawstwo podżegania i pomocnictwa, które nie są sprawstwem przestępstwa rodzajowego. Podobnie rzecz się ma w nauce niemieckiego prawa karnego. Również tam rozróżnia się formy sprawstwa oraz uczestnictwa, przy czym sprawstwo uczestników nie jest postacią sprawstwa przestępstwa rodzajowego.

Oznacza to, że pomimo istotnego zmodyfikowania teoretycznych podstaw odpowiedzialności karnej za przestępne współdziałanie polska nauka prawa karnego nie przyjęła wprost założeń ani Teilnahmesystem ani Einheitstätersystem. Wyodrębnienie postaci współdziałania przestępnego ma w polskim k.k. z $1997 \mathrm{r}$. inną podstawę aniżeli w prawie niemieckim czy austriackim. W prawie niemieckim ta podstawa jest rozszerzenie zakresu odpowiedzialności wynikającego $\mathrm{z}$ ujęcia znamion czasownikowych typów przestępstw opisanych w części szczególnej z powodu przyczynienia się do ich wykonania. W prawie austriackim regulacja form sprawstwa ogranicza zakres karalności. Z kolei w prawie polskim podstawą wyodrębnienia przez ustawodawcę form sprawstwa oraz podżegania i pomocnictwa jest opisanie odmiennych zachowań na różne sposoby zagrażajacych dobrom prawnym.

Podżeganie i pomocnictwo nie sa postaciami zjawiskowymi popełnienia przestępstwa, ale typami zjawiskowymi czynu zabronionego. Typem zjawiskowym jest takie zachowanie, które ustawodawca opisuje przez regulację części ogólnej i wysunięcie przed nawias opisu zachowania osoby, która przyczynia się do popełnienia przez innego człowieka czynu realizującego stan rzeczy opisany w części szczególnej, stanowiący typ przestępstwa rodzajowego. Ten ostatni zawsze jest opisany w części szczególnej ustawy karnej i stanowi pod-

op. cit., s. 595. Zob. także postanowienie SN z 29 kwietnia 2009 r., I KZP 6/09, OSNKW 2009, nr 6, poz. 43; wyrok SA w Łodzi z 13 marca 2008 r., II AKa 17/08, „Prokuratura i Prawo” 2009, z. 5 , poz. 14 .

${ }_{25}$ A. Kalinka, O podżegaczach $i$ sprawcach występków, Kraków 1839, s. 10-11.

${ }^{26}$ E. Krzymuski, Wykład prawa karnego, Kraków 1911, s. 418. Zob. także L. Tyszkiewicz, op. cit., s. 141-142.

${ }^{27}$ W. Wolter, Zagadnienie uczestnictwa w przestepstwie, „Nowe Prawo” 1955, z. 7-8, s. 38.

${ }^{28}$ S. Śliwiński, Polskie prawo karne materialne. Część ogólna, Warszawa 1946, s. 345.

29 J. Śliwowski, Prawo karne, Warszawa 1979, s. 238. 
stawowy, rodzajowy sposób zagrożenia dobra prawnego. Ustawodawca, uzupełniając zakres odpowiedzialności karnej, może modyfikować znamiona tak opisanego rodzajowego typu przestępstwa przez formułowanie jego form stadialnych albo posłużyć się opisem typu rodzajowego do skonstruowania typu zjawiskowego.

Typy zjawiskowe podżegania i pomocnictwa stanowią czyny zabronione o samodzielnym zespole ustawowych znamion. Na każdy typ podżegania składają się znamiona wysłowione w art. $18 \S 2 \mathrm{k}$.k. oraz znamiona tego typu czynu zabronionego, którego dokonanie przez inną osobę stanowi cel podżegacza lub przedmiot zamiaru pomocnika.

Tak opisany typ zjawiskowy podżegania jest bliski regulacji podżegania i pomocnictwa jako form uczestnictwa w czynie innej osoby, a więc do założeń zmodyfikowanej teorii udziału. Różnica sprowadza się tu do tego, że o ile w niemieckim prawie karnym podżeganie i pomocnictwo ujmowane sa przede wszystkim jako formy współdziałania i uczestnictwa w cudzym przestępstwie, co skutkuje ich akcesoryjnym charakterem, o tyle typy zjawiskowe przestępstwa są konstruowane ze szczególnym naciskiem na niebezpieczeństwo tkwiące w samym podżeganiu i pomocnictwie. Ich niezależność ma tu silniejszą podstawę, co uzasadnia odstapienie od akcesoryjności odpowiedzialności.

\section{UWAGI DE LEGE FERENDA}

Ukształtowanie podżegania i pomocnictwa jako typów zjawiskowych przestępstwa czyni aktualnym pytanie o potrzebę odmiennej regulacji zasad odpowiedzialności karnej za przestępne współdziałanie. Jak już wcześniej wskazywano, polski ustawodawca w kodeksach z 1969 r. i 1997 r. rozszerzył pojęcie sprawstwa, uznając, że odpowiada za sprawstwo nie tylko ten, kto wykonuje czyn zabroniony sam albo wspólnie i w porozumieniu z inna osoba, lecz także ten, kto kieruje wykonaniem czynu zabronionego lub wykorzystując uzależnienie innej osoby od siebie, poleca jej wykonanie takiego czynu. Sprawstwo kierownicze i polecające, jako równorzędne sprawstwu pojedynczemu i współsprawstwu formy popełnienia przestępstwa rodzajowego, stanowia jego postacie zjawiskowe w takim rozumieniu, jakie temu pojęciu nadawał J. Makarewicz ${ }^{30}$.

Wszystkie formy współdziałania (kierownictwo, polecenie, nakłanianie, pomoc) zostały zrelatywizowane do wykonania lub dokonania przez sprawcę czynu zabronionego, a więc zachowania o znamionach określonych w ustawie karnej (art. $115 \S 1$ k.k.). Oznacza to, że czyn sprawcy, przy wykonaniu którego współdziała sprawca kierowniczy lub polecający oraz podżegacz lub pomocnik, muszą się de lege lata charakteryzować takimi właściwościami, że gdyby wykonawca go wykonał, stanowiłby czyn zabroniony. Jeżeli zachowanie wykonawcy nie nosiłoby wszystkich znamion typu, o czym współdziałający

${ }^{30}$ A. Zoll, Czy podżeganie i pomocnictwo..., s. 723-724. 
wie, nie może być mowy o sprawstwie kierowniczym, polecającym, podżeganiu czy pomocnictwie ${ }^{31}$.

W dyskusjach przedstawicieli nauki prawa karnego wskazywano także na inne luki wynikające $\mathrm{z}$ ustawowego ujęcia form współdziałania przestępnego ${ }^{32}$. Wydaje się, że można ich uniknaćć, zastępując formy sprawstwa kierowniczego i polecającego sprawstwem pośrednim. Taki kierunek zdaje się wynikać ze zmian, jakim podlegało polskie prawo karne. Pomimo deklaracji wierności teorii postaci zjawiskowych, których założeniem jest równorzędność wszystkich form popełnienia przestępstwa, kolejne reformy prawa karnego rozszerzyły pojęcie sprawstwa kosztem podżegania i pomocnictwa. Skoro ustawodawca dostrzegał potrzebę zakwalifikowania pewnych zachowań, które mogłyby być kwalifikowane jako podżeganie lub pomocnictwo, jako sprawstwa, to tym samym opowiedział się za poglądem, zgodnie z którym to sprawstwo stanowi podstawową formę popełnienia przestępstwa, regulacja podżegania i pomocnictwa ma zaś względem sprawstwa charakter uboczny, subsydiarny. Potrzeba posługiwania się konstrukcją sprawstwa pośredniego wynika także z analizy szeregu wypowiedzi przedstawicieli nauki prawa karnego i judykatury, dostrzegajacych luki w kryminalizacji form współdziałania przestępnego ${ }^{33}$.

Usankcjonowanie postaci sprawstwa pośredniego wymagałoby zmiany zakresu podżegania i pomocnictwa. Wydaje się, że przedmiotem czynów podżegacza i pomocnictwa powinno być de lege ferenda bezprawne zachowanie innej osoby. Podżegacz i pomocnik, działajacc w zamiarze, aby inna osoba dokonała czynu zabronionego, realizują wszakże także własny zamiar przestępny. Jest to szczególnie istotne przy podżeganiu, jego znamieniem jest wszakże zamiar bezpośredni, którego przedmiotem jest de lege lata dokonanie czynu zabronionego przez inną osobę ${ }^{34}$. W przypadku zastapienia sprawstwa kierowniczego i polecającego formą sprawstwa pośredniego większość wątpliwych stanów faktycznych (takich jak podżeganie do przestępstwa nieumyślnego, współdziałanie przy czynie nienoszącym znamion czynu zabronionego czy wykorzysta-

${ }^{31}$ Dyskusyjna w tym kontekście jest możliwość odpowiedzialności współdziałającego przy przestępstwie indywidualnym, jeśli to współdziałajacy niewykonujący czynu zabronionego posiada cechę wymaganą od sprawcy, a nie posiada jej wykonawca. Wymaga to szczegółowej analizy art. $21 \S 2$ k.k. i przekracza ramy opracowania (por. A. Zoll, Glosa do wyroku Sadu Najwyższego $z$ dnia 25 czerwca 2008 r., IV KK 39/08, OSP 2009, z. 3, s. 172-173).

${ }^{32}$ Ich omówienie przekraczałoby ramy pracy. Chodzi w szczególności o podżeganie (pomocnictwo) z elementem nieumyślności, w tym niewłaściwe podżeganie do przestępstwa nieumyślnego oraz przypadek, gdy ktoś realizuje własny zamiar przestępny, wykorzystując zachowanie innej osoby, nieświadomej przyczynienia się do powstania ujemnego stanu rzeczy, odpowiadającego opisowi znamion przedmiotowych typu przestępstwa.

${ }^{33}$ Zob. w szczególności Z. Jędrzejewski, Podżeganie (pomocnictwo), sprawstwo kierownicze i sprawstwo pośrednie a akcesoryjność odpowiedzialności, w: Z. Jędrzejewski et al. (red.), Między naukq a praktyka prawa karnego. Księga jubileuszowa Profesora Lecha Gardockiego, Warszawa 2014, s. 126-129, s. 137-138 i A. Zoll, Sprawstwo..., s. 183. W orzecznictwie zob. zwłaszcza wyrok SO w Piotrkowie Trybunalskim z 5 grudnia 2014 r., IV Ka 649/14, www.orzeczenia.potrkow-tryb. so.gov.pl; wyrok SO w Poznaniu z 7 października 2015 r., XVII Ka 800/15, www.orzeczenia.poznan.so.gov.pl.

${ }^{34}$ Ł. Pohl, op. cit., s. 165; P. Kardas, op. cit., s. 649-650; Zob. także wyrok SA w Krakowie z 9 lutego 2011 r., II AKa 103/10, „Prokuratura i Prawo” 2011, z. 11, poz. 28; wyrok SN z 10 listopada 2009 r., II KK 155/09, OSNwSK 2009, z. 1, poz. 2252. 
nie osoby nieświadomej do zrealizowania własnego zamiaru) zostałoby przez tę formę pochłonięte. Wydaje się jednak, że nie należy rezygnować z szerszego ujęcia podżegania i pomocnictwa jako form pokrewnych sprawstwu pośredniemu. Sprawstwo pośrednie i podżeganie należy więc rozróżniać, uwzględniając w szczególności sprawowane przez sprawcę pośredniego władztwo nad czynem wykonawcy ${ }^{35}$.

Rozszerzenie pojęcia sprawstwa przez zastapienie kierowania i wydania polecenia z wykorzystaniem stosunku zależności formą sprawstwa pośredniego, a także rozszerzenie podżegania i pomocnictwa na współdziałanie przy czynie bezprawnym, ale niekoniecznie czynie zabronionym, powinno skutkować ograniczeniem odpowiedzialności za podżeganie i pomocnictwo w płaszczyźnie akcesoryjności. Uwzględniając poglądy przedstawicieli nauki polskiego prawa karnego i judykatury, uważam, że nie byłoby uzasadnione wprowadzenie kwalifikatywnej akcesoryjności odpowiedzialności podżegacza i pomocnika. Wydaje się jednak, że dokonanie przestępstwa przez podżegacza i pomocnika powinno zostać uzależnione od dokonania czynu przez nakłanianego lub adresata pomocy. Surowa represja grożąca podżegaczowi i pomocnikowi wydaje się nie do pogodzenia z przyjmowanym niemal powszechnie momentem dokonania podżegania i pomocnictwa, którym jest, odpowiednio, wywołanie w nakłanianym decyzji określonego zachowania lub obiektywne ułatwienie popełnienia czynu zabronionego. Dokonanie czynu przez wykonawcę świadczy o skuteczności zachowania podżegacza lub pomocnika i stwarza opisane w przepisie typizującym części szczególnej zagrożenie dobra prawnego. Wszystkie te względy prowadzą do wniosku, że należy w ustawie usankcjonować intencjonalny i strukturalny związek pomiędzy podżeganiem i pomocnictwem a sprawstwem głównym ${ }^{36}$. Dokonanie czynu przez wykonawcę powinno być objęte zamiarem podżegacza lub pomocnika, ale ustawa nie powinna wymagać, by zachowania te łączył związek przyczynowy i węzeł obiektywnego przypisania skutku. Należy się wszakże zgodzić z poglądami tych autorów, którzy zwracają uwagę na niemożliwe do pokonania przeszkody natury dowodowej, gdy przychodzi do udowodnienia, że zachowanie wykonawcy było wynikiem akurat działalności podżegacza lub pomocnika ${ }^{37}$.

Ukształtowanie podżegania i pomocnictwa jako typów zjawiskowych ilościowo akcesoryjnych względem sprawstwa głównego pozwala na konstruowanie odpowiedzialności za ich usiłowanie ${ }^{38}$. Dystansuje to koncepcję typów zjawiskowych od teorii udziału w cudzym czynie.

35 Podobnie rozgranicza się sprawstwo pośrednie oraz formy uczestnictwa we współczesnym niemieckim prawie karnym. Zob. P. Hünerfeld, op. cit., s. 204-205; R. Herzberg, op. cit., s. 147 148.

${ }^{36}$ L. Tyszkiewicz, Czy nowelizacja przepisów o podżeganiu i pomocnictwie jest potrzebna?, „Państwo i Prawo” 68, 2013, z. 11, s. 103-105.

37 Idem, Glosa do wyroku Trybunału Konstytucyjnego z dnia 17 lipca 2014 r., sygn. SK 35/12, „Prokuratura i Prawo” 2015, z. 7-8, s. 270.

${ }_{38}$ Analiza publikowanego orzecznictwa sądowego prowadzi do wniosku, że przypadki usiłowania podżegania spotykają się niejednokrotnie z surową represją karną. Zob. wyrok SA w Lublinie z 13 lutego 2013 r., II AKa 166/12, Lex nr 1294819; wyrok SA w Warszawie z 7 lutego 2013 r., II AKa 370/12, Lex; wyrok SA w Warszawie z 14 sierpnia 2009 r., II AKa 220/09, Legalis; postano- 
Jak już wyżej wskazywano, brak władztwa podżegacza i pomocnika nad czynem wykonawcy powinien skutkować zmniejszeniem zagrożenia karą. Podstawą wymiaru kary grożącej podżegaczowi lub pomocnikowi powinien być przepis typizujący, opisujący typ rodzajowy czynu zabronionego, którego realizacji chce podżegacz. Ponieważ podżeganie i pomocnictwo de lege feren$d a$ byłby relatywizowane do wykonanego przez wykonawcę czynu bezprawnego, w procesie subsumcji należałoby zidentyfikować przepis uzupełniający znamiona podżegania przez rekonstrukcję zamiaru podżegacza/pomocnika. Współdziałający, nakłaniając inną osobę do dokonania określonego bezprawnego czynu lub udzielając mu pomocy do dokonania takiego czynu, chca spowodowania przez nich stanu rzeczy realizujacego znamiona przedmiotowe typu rodzajowego (w szczególności skutku), nawet jeśli z różnych przyczyn wykonawca tych znamion nie zrealizuje. Irrelewantna byłaby wyobrażona przez podżegacza czy pomocnika strona podmiotowa czynu, jakiego ma się dopuścić wykonawca, gdyż przedmiotem podżegania i pomocnictwa byłby, de lege ferenda, czyn bezprawny. Wyjątkiem byłby więc przypadek, gdy zachowanie, do dokonania którego podżegacz nakłania inną osobę lub w której dokonaniu pomocnik udziela pomocy, może być bezprawne tylko wówczas, gdy wykonawca przejawi nastrój woli, od którego zależy bezprawność. Podżegacz i pomocnik zawsze odpowiadaliby za przestępstwo, którego kwalifikacja uwzględniałaby art. 18 § 2 lub 3 k.k. oraz przepis zawarty w części szczególnej konstruujacy typ przestępstwa umyślnego ${ }^{39}$. Na podstawie tego przepisu wymierzano by także karę podżegaczowi lub pomocnikowi.

Konkludujacc, 18 § 2 i 3 mogłyby uzyskać następujące brzmienie: „§ 2. Kto chcąc, aby inna osoba dokonała czynu bezprawnego, nakłania ją do tego, odpowiada za podżeganie. $\S 3$ Kto w zamiarze, aby inna osoba dokonała czynu bezprawnego, swoim zachowaniem ułatwia jego popełnienie, w szczególności dostarczając narzędzie, środek przewozu, udzielając rady lub informacji, odpowiada za pomocnictwo. Odpowiada za pomocnictwo także ten, kto wbrew prawnemu, szczególnemu obowiązkowi niedopuszczenia do popełnienia czynu bezprawnego swoim zaniechaniem ułatwia innej osobie jego popełnienie".

Artykuł 19 mógłby uzyskać następujące brzmienie: „Artykuł $19 \S 1$. Jeżeli sprawca dokona czynu, sąd wymierza karę za sprawstwo pośrednie, podżeganie lub pomocnictwo na podstawie przepisu określającego umyślny czyn zabroniony objęty ich zamiarem. $§ 2$. Sąd wymierza karę za podżeganie i po-

wienie SN z 29 kwietnia 2009 r., I KZP 6/09, OSNKW 2009, z. 6, poz. 43; wyrok SN z 28 listopada 2006 r., III KK 156/06, OSNwSK 2006, z. 1, poz. 2264; wyrok SA we Wrocławiu z 8 czerwca 2006 r., II AKa 135/06, „Prokuratura i Prawo” 2007, z. 4, poz. 28; wyrok SN z 7 września 2004 r., WK 18/04, OSNwSK 2004, z. 1, poz. 1510; wyrok SO w Koszalinie z 14 maja 2013 r., II K 8/13, www. orzeczenia.ms.gov.pl; uchwała (7) SN z 21 października 2003 r., I KZP 11/03, OSNKW 2003, z. 1112, poz. 89; wyrok SA w Lublinie z 21 stycznia 2014 r., II AKa 200/13, www.orzeczenia.ms.gov.pl; Legalis; wyrok SA we Wrocławiu z 14 lutego 2013 r., II AKa 1/13, www.orzecznia.wroclaw.sa.gov. pl; wyrok SA w Krakowie z 22 maja 2014 r., II AKa 130/14, „Krakowskie Zeszyty Sądowe” 2014, z. 12 , poz. 57 .

${ }^{39}$ Jak się zdaje, tzw. właściwe podżeganie do przestępstwa nieumyślnego, a więc wprowadzenie w błąd wykonawcę przez nakłaniającego tak, aby popełnił on nieumyślnie czyn zabroniony i sprowadził skutek objęty zamiarem bezpośrednim podżegacza, należałoby ocenić de lege ferenda jako sprawstwo pośrednie. 
mocnictwo w wysokości od dolnej granicy ustawowego zagrożenia zmniejszonej o połowę do wysokości nieprzekraczajacej 2/3 górnej granicy ustawowego zagrożenia przewidzianego za czyn określony w $\S 1$ ”.

Dotychczasowa regulacja art. 22 , de lege ferenda regulujacca szczególne dyrektywy wymiaru kary za usiłowanie podżegania, powinna zostać przeniesiona do art. 19a, który mógłby uzyskać następujące brzmienie: „§ 1. Jeżeli sprawca nie dokonał czynu, o którym mowa w art. $19 \S 1$, sprawca pośredni, podżegacz i pomocnik odpowiadają za usiłowanie. § 2. Skazując za usiłowanie podżegania lub pomocnictwa, sąd stosuje nadzwyczajne złagodzenie kary, a nawet może odstapić od jej wymierzenia, przy czym art. 19a § 2 stosuje się”.

Zaproponowane wyżej brzmienie odpowiednich przepisów rozdziału II Kodeksu karnego może stanowić podstawę do dyskusji o potrzebie zmian w regulacji zasad odpowiedzialności karnej za przestępne współdziałanie. Jeżeli dyskusję taką udałoby się otworzyć, cel założony przez autora powyższych rozważań byłby spełniony.

dr Damian Tokarczyk

adwokat, Warszawa

damian.tokarczyk@adwokatura.pl

\section{AIDING AND ABETTING AS A CRIME}

\section{Sum mary}

The article is an attempt at a different look at aiding and abetting in criminal law. The provisions of the Penal Code of 1997 are analysed against the background of model solutions of criminal liability for aiding and abetting and the modern modifications of this crime. It deals with deviations from the theory of crime, the participation in criminal acts committed by others and criminal acts perpetrated by individuals acting independently. While analysing the current wording of the provisions governing criminal liability for aiding and abetting, the author proposes that they be classified as certain types of criminal acts. Further, proposing a different view on the construction of types of prohibited acts, he identifies provisions of the existing Penal Code that ought to be amended. 